\title{
Scyphozoan jellyfish provide short-term reproductive habitat for hyperiid amphipods in a temperate near-shore environment
}

\author{
Nicholas E. C. Fleming ${ }^{1,2, *}$, Chris Harrod ${ }^{1,3,4}$, Donal C. Griffin ${ }^{1}$, Jason Newton ${ }^{5}$, \\ Jonathan D. R. Houghton ${ }^{1,2}$ \\ ${ }^{1}$ School of Biological Sciences, Queen's University Belfast, Medical Biology Centre, 97 Lisburn Road, Belfast BT9 7BL, UK \\ ${ }^{2}$ Queen's University Belfast Marine Laboratory, 12-13 The Strand, Portaferry, Co. Down, BT22 1PF, UK \\ ${ }^{3}$ Instituto de Ciencias Naturales Alexander Von Humboldt, Universidad de Antofagasta, Avenida Angamos 601, Antofagasta, \\ Chile \\ ${ }^{4}$ School of Biological and Chemical Sciences, Queen Mary University of London, Mile End Road, London E1 4NS, UK \\ ${ }^{5}$ NERC Life Sciences Mass Spectrometry Facility, Scottish Universities Environmental Research Centre, Scottish Enterprise, \\ Technology Park, East Kilbride G75 0QF, UK
}

\begin{abstract}
Hyperiid amphipods (Order Amphipoda, Suborder Hyperiidea) are known to infest gelatinous zooplankton. However, the temporal backdrop to these associations is less clear, given that data are often gathered during discrete sampling events rather than over time. In general, hyperiids are considered to be pelagic: however, for individuals associated with metagenic jellyfishes in temperate shallow shelf seas, this may not always be the case, as the majority of their gelatinous hosts are present in the water column from spring to the onset of autumn. Here, we explored the temporal patterns of colonisation and overall duration of the association between Hyperia galba and 3 scyphozoan jellyfish species (Aurelia aurita, Cyanea capillata and C. lamarckii) in a temperate coastal system (Strangford Lough, Northern Ireland) during 2010 and 2012. Concomitantly, we used carbon and nitrogen stable isotope ratios to examine whether hyperiid infestation represented a permanent association with their host or was part of a more complex life history. We found that jellyfish were colonised by $H$. galba ca. 2 mo after they are first observed in the lough and that $H$. galba reached $100 \%$ prevalence in the different jellyfish species shortly before the medusae of each species disappeared from the water column. It is possible that some jellyfish overwintered in deeper water, prolonging the association between $H$. galba and their hosts. However, all the medusae sampled during the spring and early summer (whether they were newly emerged or had overwintered from the previous season) were not infected with hyperiids, suggesting that such behaviour was uncommon or that individuals had become dissociated from their host during the winter. Further evidence of temporary association came from stable isotope data, where $\delta^{13} \mathrm{C}$ and $\delta^{15} \mathrm{~N}$ isotope ratios were indicative of feeding outside of their host prior to jellyfish colonisation. In combination, these findings suggest alternating habitat associations for $H$. galba, with the amphipods spending the majority of the year outside of the 3 scyphozoan species considered here.
\end{abstract}

KEY WORDS: Hyperiid amphipod · Scyphozoan · Medusae · Stable isotope analysis · Diet composition · Bayesian analysis

\section{INTRODUCTION}

Emphasis on the detrimental impacts of gelatinous zooplankton (or 'gelata') can overshadow the role of these species in the provision of ecosystem services (Doyle et al. 2014). Within pelagic systems, gelata are renowned for providing an important source of energy and nutrients to large-bodied pelagic con- 
sumers including reptiles and fishes (Houghton et al. 2006, Heaslip et al. 2012, Harrod et al. 2013), but they also provide a physical habitat that benefits a wide variety of species (Kingsford 1993, Ohtsuka et al. 2009). Gelata provide refugia and nursery/feeding habitats for juveniles and adults of many other invertebrate species (e.g. Marliave \& Mills 1993, Pagès et al. 2007, Sal Moyano et al. 2012). Various commercial fish are also found in association with gelata during early life stages, often using the bell or tentacles as protection from other predators (e.g. Mansueti 1963, Lynam \& Brierly 2007).

Perhaps the most well-documented association with gelata is that of the hyperiid amphipods, examples of which have been recorded from the deep ocean (Gasca \& Haddock 2004, Lindsey \& Pagès 2010) to shallow neritic waters (Metz 1967, Dittrich 1988, Towanda \& Theusen 2006). Hyperiid amphipods are considered typically as a pelagic group (Vinogradov et al. 1996, Martin \& Davis 2001). In offshore environments, they are known to form parasitic associations with holoplanktonic gelata such as salps, pyrosomes and ctenophores (Harbison et al. 1977, Laval 1980), although not exclusively, as hyperiids constitute a major component of crustacean zooplankton (Bowman \& Gruner 1973). Previous studies have placed emphasis on the role of gelata as the primary habitat for hyperiids, especially in open/deep waters (Harbison et al. 1977, Madin \& Harbison 1977, Laval 1980), and this rationale has been extended to the near-shore environment where hyperiids are found most commonly in association with true jellyfish (i.e. Phylum Cnidaria; Class Scyphozoa) during summer months (e.g. Dittrich 1988, Buecher et al. 2001).

In temperate coastal systems, the association between scyphozoan jellyfish and hyperiid amphipods is best described for Hyperia galba (Montagu, 1815), an arctic-boreal member of the Suborder Hyperiidae (Bowman 1973, Dittrich 1991). There is clear evidence that $H$. galba use scyphozoans during the reproductive phase of their life cycle, demarsupiating on medusae and inserting their brood into the mesoglea of the host (Dittrich 1987, 1988, 1992). It remains unclear, however, whether such species constitute the primary habitat for hyperiids in coastal seas, given that the majority of medusae are only present in the water column from the start of spring through to the onset of autumn (Russell 1970, Lucas 2001, Barz \& Hirche 2005). Unfortunately, very little is known about the habitat of $H$. galba when not in association with gelata (Dittrich 1988), as sampling is normally directed towards the host itself. Despite this paucity of data, Dittrich $(1988,1992)$ advanced the discussion by suggesting a period of hibernation or a slow-developing (possibly benthic) existence for $H$. galba throughout the winter, followed by a fast-growing and reproductive pelagic phase when scyphozoan jellyfish were present in the water column. Although logical, this argument may need refinement considering that an 'overwintering' period in the benthos would constitute $\sim 8$ mo of the year, given the seasonal presence of temperate scyphozoan medusae. As there is no evidence to our knowledge that $H$. galba aggregate in the water column (unlike their oceanic counterparts), the logical assertion is that the species may spend more time in the benthos than previously considered.

To test the hypothesis that predation on gelatinous tissue and diapause alone could not account for the year-round survival of hyperiids, we tested for evidence of assimilation of energy and nutrients from other alternative trophic pathways (benthic, pelagic) in individuals collected from 3 species of scyphozoan jellyfish in 2010. Building on this conjecture, if hyperiids are able to survive for protracted periods outside of their gelatinous hosts, then predation is not necessarily the ultimate driver of this association. Subsequently, we tested whether scyphozoa in temperate near-shore environments served primarily as a seasonally abundant prey source (indicated by consistent or long-term infestation) or as a temporary reproductive habitat for brood deposition and on-growing. Lastly, we considered whether the prevalence of infestation by hyperiids was uniform across the 3 scyphozoan species, and if not, what factors might drive such differences.

\section{MATERIALS AND METHODS}

\section{Study site}

Strangford Lough in Northern Ireland $\left(54^{\circ} 28^{\prime}\right.$ $20.98^{\prime \prime} \mathrm{N}, 5^{\circ} 35^{\prime} 10.60^{\prime \prime} \mathrm{W}$ ) is a large coastal inlet covering $150 \mathrm{~km}^{2}$. The Narrows is a $0.5 \mathrm{~km}$ wide channel which connects the main body of the Lough to the Irish Sea and is ca. $10 \mathrm{~m}$ deep at the site of jellyfish collection. Currents in the Narrows can reach up to $3.5 \mathrm{~m} \mathrm{~s}^{-1}$ (Magorrian et al. 1995), and the waters are well-mixed at all times. There are 2 main rivers feeding into the Lough but they have low discharge, and the Lough maintains salinities of between 32 and 35 (Erwin 1986). 


\section{Collection of jellyfish and associated hyperiids}

Three species of scyphozoan jellyfish and associated hyperiids were collected from Strangford Lough during 2010 and 2012: Aurelia aurita (Linnaeus, 1758), Cyanea lamarckii (Peron \& Lesurer, 1810) and C. capillata (Linnaeus, 1758). Medusae were collected monthly (owing to budgetary constraints and adverse weather conditions) in 2010 and weekly in 2012. Sampling dates were considered as weeks and standardised relative to the first observation of medusae during the entire study period (i.e. Week $1=7$ to 13 May, Week $17=30$ August to 5 September). Individual medusae were collected in the top metre of the water column from a small boat using dip nets (mesh size $1 \mathrm{~mm}$ ). High velocity tidal flows in Strangford Lough inhibit active vertical migration of the medusae, and they are routinely circulated throughout the well-mixed water column. In this context, attributing medusae to specific depths in the water column through stratified sampling protocols (e.g. Angel \& Pugh 2000) was deemed unnecessary. Consequently, individuals collected near the surface were considered representative of the population as a whole. Immediately after removal from the water, each medusa was placed into an individual bucket to isolate the associated fauna. All hyperiids $>2 \mathrm{~mm}$ (juveniles and adults) were removed from their host under laboratory conditions and identified to species level using Bowman (1973) and Hayward et al. (1995).

\section{Spatial and temporal patterns of hyperiid infestation}

To establish a timeframe for infestation, hyperiid prevalence (i.e. the extent of host infestation) was determined for the 3 gelatinous species encountered during each sampling week in 2010 and 2012. This measure allowed the presence or absence of Hyperia galba in a sample of hosts to be expressed as a percentage (number of infected medusae/number of sampled medusae) following Bush et al. (1997). Mean hyperiid infection intensity (i.e. the average number of $H$. galba per infected medusa) was calculated additionally for each species during each sampling week. Bias-corrected confidence intervals around the means were calculated using an accelerated bootstrap approach $\left(\mathrm{BC}_{\mathrm{a}}\right)$ following Efron \& Tibshirani (1993) and Rózsa et al. (2000). A variance to mean ratio (VMR) was calculated to establish whether $H$. galba were over-dispersed or distributed randomly amongst their hosts, based on the methods of Barbour \& Pugliese (2000) and Rózsa et al. (2000).

\section{Hyperiid sex ratios and life stage}

To test the hypothesis that scyphozoan jellyfish in Strangford Lough served as reproductive habitat for brood deposition and on-growing, we collected sex and life stage (adult or juvenile) data for associated amphipods where possible. Individual hyperiids were measured $( \pm 1 \mathrm{~mm})$ whilst stretched out under a stereo binocular microsope and sexed if $>3 \mathrm{~mm}$ (i.e. the length at which secondary sexual characteristics become evident). Measurements were taken from the anterior edge of the head (not including antennae) to the telson tip (not including uropods) following Dittrich (1988). Body length (BL) of $H$. galba was used as an indicator of life history stage, with juveniles taken as individuals $<7 \mathrm{~mm}$ (following Dittrich 1988). To test whether there was a predominance of either sex of $H$. galba found on medusae, the numbers of sexed individuals were converted into a female to male ratio and a $G$-test was used to determine any differences from a 1:1 sex ratio.

\section{Stable isotope analysis (SIA)}

The second hypothesis relating to infestation was that scyphozoans served primarily as a seasonally abundant prey source. A. aurita, C. lamarckii and C. capillata were weighed and measured (wet mass: $\pm 1 \mathrm{~g}$; bell diameter: $\pm 1 \mathrm{~cm}$ ), dried at $60^{\circ} \mathrm{C}$ (Fleming et al. 2011) then desiccated for $48 \mathrm{~h}$ to prevent the absorption of water vapour during cooling. Desiccated samples were then ground to a fine powder using an agate pestle and mortar in preparation for stable isotope analysis (SIA). H. galba for SIA (collected in 2010) were kept alive in separate containers with aeration for $24 \mathrm{~h}$ to allow gut clearance. The H. galba from 2012 were preserved in $70 \% \mathrm{EtOH} /$ seawater and were not used for SIA to avoid potential preservation effects on isotopic values. The 2012 hyperiids were used solely for the determination of sex ratios and life stage. The $2010 \mathrm{H}$. galba samples were oven-dried $\left(60^{\circ} \mathrm{C}\right)$ for $48 \mathrm{~h}$ and then decalcified to remove inorganic carbon (following Jacob et al. 2005). Samples were placed on a watch glass, and $0.1 \mathrm{M}$ $\mathrm{HCl}$ was added drop-by-drop until bubbling ceased (observed under dissecting microscope; see Carabel et al. 2006). The samples were re-dried for a further $24 \mathrm{~h}$ then prepared in the same way as the jellyfish samples for SIA.

Within marine systems, $\delta^{15} \mathrm{~N}$ is typically used as an indicator of the trophic position inhabited by an organism (consumer) within a food web, whilst $\delta^{13} \mathrm{C}$ 
is used to characterise the ultimate energy source fuelling that individual, e.g. carbon originating from benthic (e.g. microalgae) or pelagic (e.g. phytoplankton) resources. Three replicate phytoplankton tows $(100 \mu \mathrm{m}$ mesh size, diameter $50 \mathrm{~cm}$, length $220 \mathrm{~cm}$ ) were conducted during each sampling day in 2010 . Phytoplankton samples were filtered through precombusted micro filters (Whatman GF/F) and dried as for jellyfish and amphipods. To characterise the benthic algal endpoint, $\delta^{13} \mathrm{C}$ and $\delta^{15} \mathrm{~N}$ values were estimated from grazing gastropods Littorina saxatilis collected from the survey area during the study period, and adjusted for trophic fractionation (Yokoyama et al. 2005) in both carbon $\left(\Delta^{13} \mathrm{C}=1 \%\right.$ o) and nitrogen $\left(\Delta^{15} \mathrm{~N}=3.5 \%\right)$.

All samples for SIA were weighed into tin cups prior to analysis; preliminary analyses determined that optimal sample mass for mass spectrometry varied between taxa (i.e. A. aurita $\approx 12 \mathrm{mg}$; . lamarckii $\approx 2.4 \mathrm{mg}, C$. capillata $\approx 5.1 \mathrm{mg}$; hyperiids $\approx 0.8 \mathrm{mg}$ ). Juvenile $H$. galba $<7 \mathrm{~mm}$ were pooled to provide adequate sample mass for mass spectrometry. Samples were analysed for $\delta^{13} \mathrm{C}$ and $\delta^{15} \mathrm{~N}, \% \mathrm{C}$ and $\% \mathrm{~N}$ at the East Kilbride Node of the Natural Environment Research Council Life Sciences Mass Spectrometry Facility via continuous flow isotope ratio mass spectrometry using an ECS 4010 elemental analyser (Costech) interfaced with a Delta XP mass spectrometer (Thermo Electron). The standard deviation of multiple analyses of an internal gelatine standard (mean \pm SD: $\delta^{13} \mathrm{C}=-20.2 \pm 0.1 ; \delta^{15} \mathrm{~N}=5.8 \pm 0.1$ ) in each experiment was $\sim 0.1 \%$ for both $\delta^{13} \mathrm{C}$ and $\delta^{15} \mathrm{~N}$.

Stable isotope data were $\log _{10}$-transformed, $\delta^{13} \mathrm{C}$ : $\log _{10}(x+40)$, to improve normality and reduce heteroscedasticity. Variation in $\delta^{13} \mathrm{C}$ and $\delta^{15} \mathrm{~N}$ values for H. galba and their scyphozoan hosts, and H. galba body length data were examined using PERMANOVA, a non-parametric probability-based analogue of analysis of variance between 2 or more groups based on a distance measure (Anderson 2001, McArdle \& Anderson 2001, Anderson et al. 2008). A similarity matrix based on Euclidean distance was created (from both $\log _{10}$-transformed isotope values and square root-transformed BL data). To establish whether $H$. galba diet was indicative of feeding in the water column, at the seabed or on their gelatinous hosts, we estimated the contribution of 3 potential resources (scyphozoan host, pelagic and benthic algae) using the mixing model function of the $R$ package SIAR (Parnell et al. 2010). To test for ontogenetic differences in hyperiid isotopic values, mean $( \pm \mathrm{SD}) \delta^{13} \mathrm{C}$ and $\delta^{15} \mathrm{~N}$ values for were calculated for all adults and juveniles collected from each species of scyphozoan in 2010. We predicted that evidence of feeding outside of their host in adult $H$. galba prior to colonisation would be reflected in ${ }^{13} \mathrm{C}$ enriched carbon stable isotope values.

The correct application of trophic enrichment factors (TEFs) is essential to ensure that outputs from mixing models are reliable (Bond \& Diamond 2011). Many studies use the 'standard' TEFs of Post (2002) (mean \pm SD: $\Delta^{13} \mathrm{C}=0.4 \pm 1.3 \%$; $\Delta^{15} \mathrm{~N}=3.4 \pm 1 \%$ ) or McCutchan et al. (2003) $\left(\Delta^{13} \mathrm{C}=0.5 \pm 1.3 \%, \Delta^{15} \mathrm{~N}=\right.$ $2.3 \pm 1.5 \%$ o) in mixing models. At present, specific TEFs are not available for hyperiid amphipods; therefore, the estimates used here $\left(\Delta^{13} \mathrm{C}=-1.5 \pm 3.0 \%\right.$, $\Delta \Delta^{15} \mathrm{~N}=1.4 \pm 1.3 \%$ ) were derived from published studies on other marine amphipods (Macko et al. 1982, Stephenson et al. 1986, Crawley et al. 2007, Farlin et al. 2010). These estimates take into consideration the low ${ }^{13} \mathrm{C}$ enrichment commonly found in detritivorous organisms (see Mancinelli 2012 and references within) and result in an unusual negative mean $\Delta^{13} \mathrm{C}$ value $(-1.5 \%)$. Sample sizes for pooled juvenile amphipods were insufficient for inclusion in the mixing models and thus were excluded from these analyses.

\section{Inter-specific patterns of amphipod density}

To consider whether the prevalence of infestation by hyperiids was uniform across the 3 host species, the number of $H$. galba encountered on each medusa was summed and standardised to density in 2 ways: as individuals per $\mathrm{cm}^{2}$ of bell surface area $\left(\pi \mathrm{r}^{2}\right)$ and as individuals per unit mass (g). Both methods were adopted as scyphozoan jellyfish do not grow isometrically, so 2 individuals with the same surface area may have markedly different tissue mass. In turn, this represents differences in the amount of habitat available to hyperiids. We also considered energy density as a proxy of prey quality with respect to infestation prevalence across the 3 gelatinous species. Individual A. aurita, C. lamarckii and C. capillata were weighed and measured (wet mass: $\pm 1 \mathrm{~g}$; bell diameter: $\pm 1 \mathrm{~cm}$ ) before preparation for bomb calorimetry following the methods of Doyle et al. (2007a). The nutritional quality, or energy density $\left(\mathrm{kJ} \mathrm{g}^{-1}\right)$, was determined for whole samples of $A$. aurita $(\mathrm{n}=5), C$. lamarckii $(\mathrm{n}=5)$ and C. capillata $(\mathrm{n}=7$ ) using an isoperibol bomb calorimeter (Parr, model 1271). The calorimeter was calibrated for the heat of combustion of $1 \mathrm{~g}$ of benzoic acid (within the range of 26.4 to $26.5 \mathrm{MJ} \mathrm{kg}^{-1}$ ). Distance-based linear model (DistLM) routines (McArdle \& Anderson 2001), an application of PERMANOVA, were performed to establish the relationship between 
H. galba density and 3 categorical and continuous predictor variables (square root-transformed surface area, wet mass and energy density). The 'Best' selection procedure was used to find the best 1-, 2- and 3 -variable model, with adjusted $\mathrm{R}^{2}$ as the selection criterion. Statistical analyses were conducted using routines in PRIMER-E v.6 (Clarke \& Gorley 2006), and R v.2.14.0 (R Development Core Team 2012).

\section{RESULTS}

\section{Overview}

Hyperiid amphipods were collected from scyphozoan medusae in Strangford Lough during 22 different sampling days in 2010 and 2012; all hyperiids were identified subsequently as Hyperia galba. In 2010, medusae were apparent near the surface from mid-May (Week 2) until late August (Week 17); a total of $308 \mathrm{H}$. galba were retrieved from 112 Aurelia aurita (14 infested medusae), $79 \mathrm{H}$. galba from 120 Cyanea lamarckii (6 infested medusae) and $100 \mathrm{H}$. galba from 77 C. capillata (17 infested medusae) (Table 1). In 2012, scyphozoans were present from mid-May (Week 1) until mid-August (Week 16) and $12 \mathrm{H}$. galba were collected from $116 \mathrm{~A}$. aurita (5 infested medusae), 89 H. galba from 142 C. lamarckii (15 infested medusae) and $40 \mathrm{H}$. galba from 134 C. capillata (11 infested medusae) (see Table 2).

\section{Temporal patterns of $\boldsymbol{H}$. galba infestation, sex ratios and life stage}

Prevalence of $H$. galba on all scyphozoan species increased from May through to the end of August in each year; $100 \%$ prevalence was reached shortly before the medusae of that species disappeared from the water column, starting with $A$. aurita, followed by $C$. lamarckii and C. capillata, respectively (Tables 1 \& 2). The predominance of VMRs of $>1$ (10 out of 13 instances; Tables 1 \& 2) show over-dispersion of H. galba (i.e. clustered or aggregated distribution). There was temporal variation in $H$. galba BL during infestation in both years; BL differed on each sampling occasion (2010: Pseudo- $F_{2,487}=8.94, \mathrm{p}<0.05 ;$ 2012: Pseudo$\left.F_{7,140}=2.42, \mathrm{p}=0.04\right)$. These temporal patterns suggest reproducing adult $H$. galba colonise initially, followed by a new generation of on-growing juveniles (Fig. 1). The adult female to male ratio differed significantly in both years from a $1: 1$ sex ratio $(2010=2.22: 1, G=$ $14.91, \mathrm{p}<0.05 ; 2012=4.33: 1, G=13.00, \mathrm{p}<0.05)$.

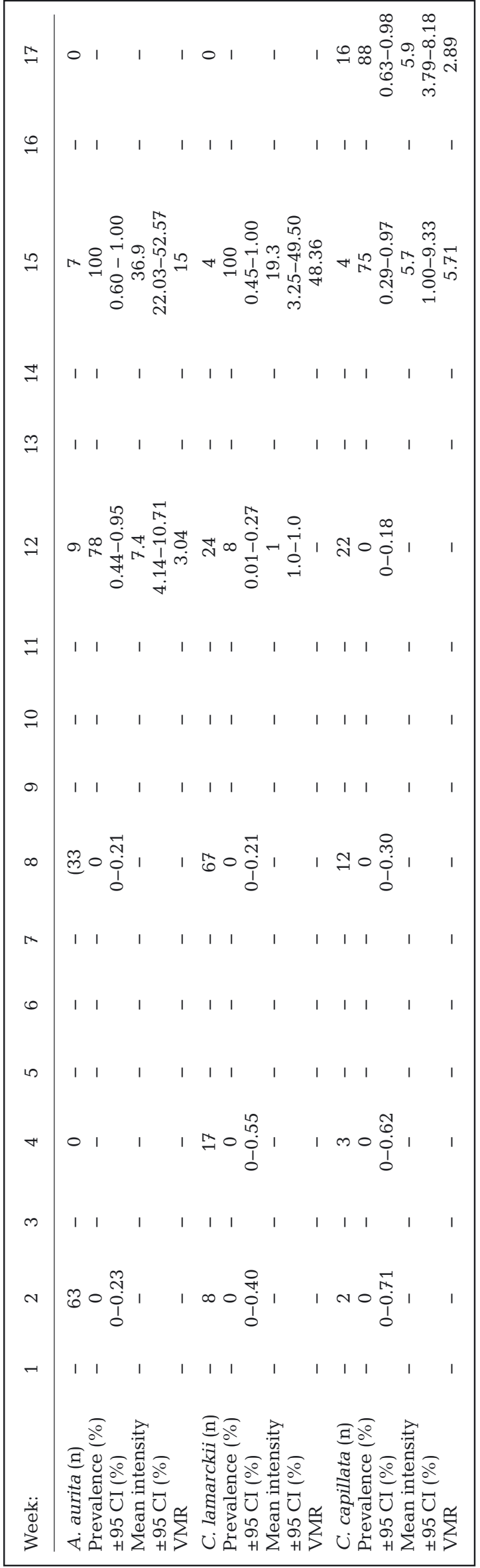




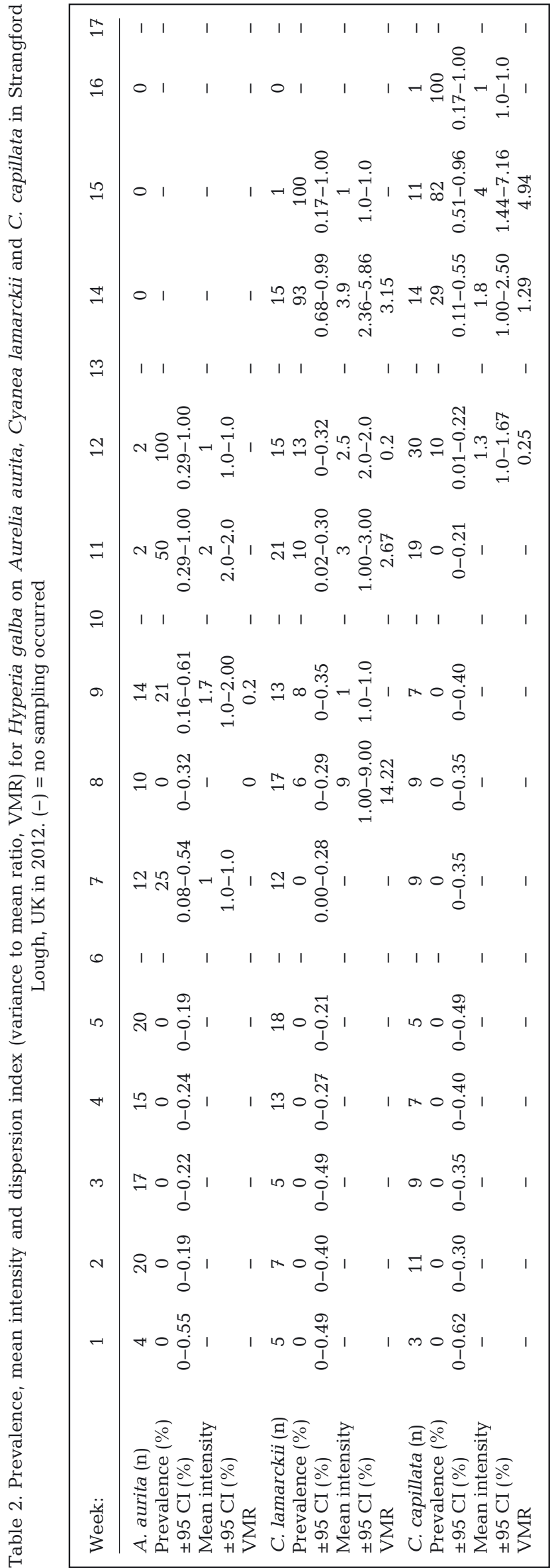

\section{Stable isotope analysis}

Stable isotope values were examined for broad consumption patterns in adult $H$. galba, including host tissues as well as pelagic and benthic algae (Table 3, Fig. 2A-C). When comparing isotopic values of $H$. galba and their gelatinous hosts, PERMANOVA revealed a significant effect of host (species $\times \log _{10}$ wet mass) on the isotopic ratios of $\mathrm{C}$ and $\mathrm{N}$ in $H$. galba (Pseudo- $F_{2,478}=3.90, p=0.02$ ). Pairwise comparisons showed isotope ratios of $H$. galba associated with $A$. aurita were different from both $C$. lamarckii and C. capillata $\left(t_{1,376}=5.32, \mathrm{p}<0.05\right.$ and $\left.t_{1,396}=8.77, \mathrm{p}<0.05\right)$, respectively, whilst $C$. lamarckii differed from $C$. capillata $\left(t_{1,174}=3.14, \mathrm{p}<0.05\right)$. This finding in itself does not show a trophic link between the hyperiids and their hosts, simply that the individuals associated with each scyphozoan species were isotopically different. To further explore this relationship, we tested for a correlation between individual amphipod and host isotope values. There was an overall weak correlation between host $\delta^{13} \mathrm{C}$ and $H$. galba $\delta^{13} \mathrm{C}$ (all scyphozoan species pooled; $\mathrm{r}=0.31, \mathrm{n}=74, \mathrm{p}<0.05)$ but no similar correlation between host and $H$. galba $\delta^{15} \mathrm{~N}(\mathrm{r}=-0.13, \mathrm{n}=74, \mathrm{p}=$ 0.28 ). When examined at a species-specific level, $H$. galba and $A$. aurita showed no correlations in $\delta^{13} \mathrm{C}$ $(\mathrm{r}=-0.22, \mathrm{n}=33, \mathrm{p}=0.22)$ but did in $\delta^{15} \mathrm{~N}(\mathrm{r}=-0.36$, $\mathrm{n}=33, \mathrm{p}=0.04) . H$. galba and $C$. lamarckii showed no correlation in either $\delta^{13} \mathrm{C}(\mathrm{r}=0.29, \mathrm{n}=19, \mathrm{p}=0.23)$ or $\delta^{15} \mathrm{~N}(\mathrm{r}=0.09, \mathrm{n}=19, \mathrm{p}=0.72)$. H. galba and $C$. capillata showed a strong correlation in $\delta^{13} \mathrm{C}(\mathrm{r}=0.54$, $\mathrm{n}=22, \mathrm{p}=0.01)$ but not in $\delta^{15} \mathrm{~N}(\mathrm{r}=-0.1, \mathrm{n}=22, \mathrm{p}=$ $0.99)$. Correlation analyses suggested that differences between hyperiids associated with different species of scyphozoa could not be explained by consumption of host tissues. Regarding ontogenetic shifts in diet, the comparison of isotopic values $\left(\delta^{13} \mathrm{C}\right.$ and $\delta^{15} \mathrm{~N}$ ) from adult and juvenile hyperiids from each scyphozoan species (PERMANOVA) revealed no significant differences between adults and juveniles collected from $A$. aurita (Pseudo- $F_{1,42}=0.32, \mathrm{p}=$ 0.61), C. lamarckii (Pseudo- $F_{1,18}=0.29, \mathrm{p}=0.71$ ) or $C$. capillata (Pseudo- $F_{1,21}=1.66, \mathrm{p}=0.21$ ).

$H$. galba isotope values, corrected for trophic fractionation, were plotted (see Fig. S1A-C, Table S1 in the Supplement at www.int-res.com/articles/suppl/ m510p229_supp.pdf) against putative food sources for 3 scenarios using (1) TEFs derived from the marine amphipod literature (Macko et al. 1982, Stephenson et al. 1986, Crawley et al. 2007, Farlin et al. 2010); (2) 'standard' TEF values from Post (2002) and (3) TEFs from McCutchan et al. (2003) (Fig. S1). Only 


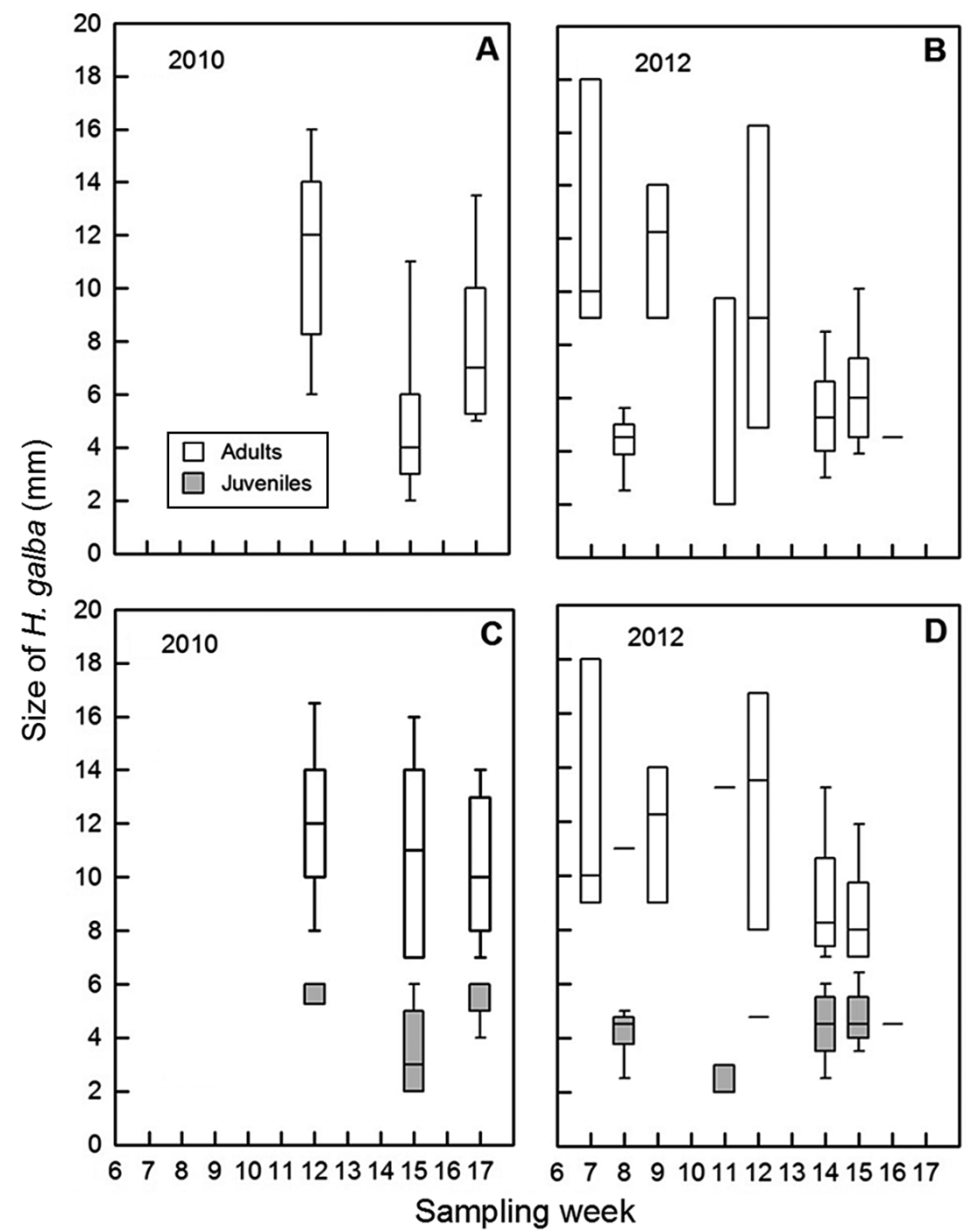

Fig. 1. Temporal variation in body length $(\mathrm{BL})$ in $(\mathrm{A}, \mathrm{B})$ Hyperia galba population as a whole, and $(C, D)$ segregated into adults and juveniles in 2010 and 2012. The H. galba population BL differed between weeks in both years (A \& B). Adult BL in both years decreased as the season progressed. Juvenile BL alternated between size classes at the beginning of the season, but showed an overall increase from Week 10 onwards in both years (C \& D)

Table 3. Hyperia galba and associated jellyfish host (Aurelia aurita, Cyanea lamarckii and C. capillata) stable isotope and C:N ratios. Means \pm SD in parentheses

\begin{tabular}{|lrccc|}
\hline Species & $\mathrm{n}$ & $\delta^{13} \mathrm{C}(\%)$ & $\delta^{15} \mathrm{~N}(\% \circ)$ & C:N \\
\hline H. galba (adult), A. aurita & 36 & $-19.0(0.5)$ & $13.1(0.9)$ & $4.2(0.3)$ \\
H. galba (juvenile), A. aurita & 7 & $-19.3(0.5)$ & $13.2(0.4)$ & $4.2(0.3)$ \\
A. aurita & 44 & $-18.5(0.8)$ & $11.5(1.2)$ & $3.6(0.3)$ \\
H. galba (adult), C. lamarckii & 17 & $-19.9(0.6)$ & $13.1(0.9)$ & $4.6(0.3)$ \\
H. galba (juvenile), C. lamarckii & 2 & $-20.3(0.6)$ & $12.8(0.7)$ & $5.2(1.5)$ \\
C. lamarckii & 37 & $-20.1(0.8)$ & $12.3(1.0)$ & $3.6(0.2)$ \\
H. galba (adult), C. capillata & 18 & $-18.8(0.6)$ & $12.8(1.3)$ & $4.4(0.3)$ \\
H. galba (juvenile), C. capillata & 5 & $-19.4(0.2)$ & $13.5(0.4)$ & $4.1(0.1)$ \\
C. capillata & 51 & $-19.8(1.5)$ & $13.8(1.5)$ & $3.2(0.5)$ \\
\hline
\end{tabular}

when data were corrected using TEFs calculated from studies of marine amphipods did consumer values fall within the isotopic mixing polygon of the potential trophic resources: as such, these TEFs were used in subsequent SIAR mixing model runs (Fig. S1, Table S1). Characterisation of dietary basal source estimates from SIAR revealed a variable but significant benthic component (benthic microalgae) in the diet of the $H$. galba associated with all 3 scyphozoan species. A. aurita mode $=0.35(95 \%$ credibility limits $=$ 0.08-0.49), C. lamarckii $=0.21$ (0.01-0.37) and C. capillata 0.42, (0.20-0.55). Pelagic sources made a lower contribution than benthic microalgae to the assimilated diet of $H$. galba associated with $A$. aurita 0.18 (0.01-0.35). For C. lamarckii, phytoplankton made a relative contribution of $0.13(0.00-0.35)$, with similar estimates obtained for $C$. capillata 0.10 (0.00-0.32) (Fig. 2D-F). Our mixing model results supported the idea that $H$. galba largely consumed the tissues of their gelatinous hosts. H. galba associated with $A$. aurita showed a contribution of host bulk tissue of 0.45 (0.28-0.81), while hyperiids collected from $C$. lamarckii had an estimated contribution of host tissues of $0.64(0.44-0.80)$. Individuals associated with $C$. capillata also assimilated a considerable proportion $0.47(0.36-0.58)$ of their diet from host tissues (Fig. 2D-F).

\section{Inter-specific patterns of amphipod density}

The prediction that inter-specific patterns of hyperiid amphipod density would be independent of host nutritional quality, size and mass was examined using DistLM. Three predictor variables (energy density, kJ $\mathrm{g}^{-1}$ dry mass (DM); bell surface area, $\mathrm{cm}^{2}$; and wet mass, g) were included in the analysis (Table 4). Wet mass 

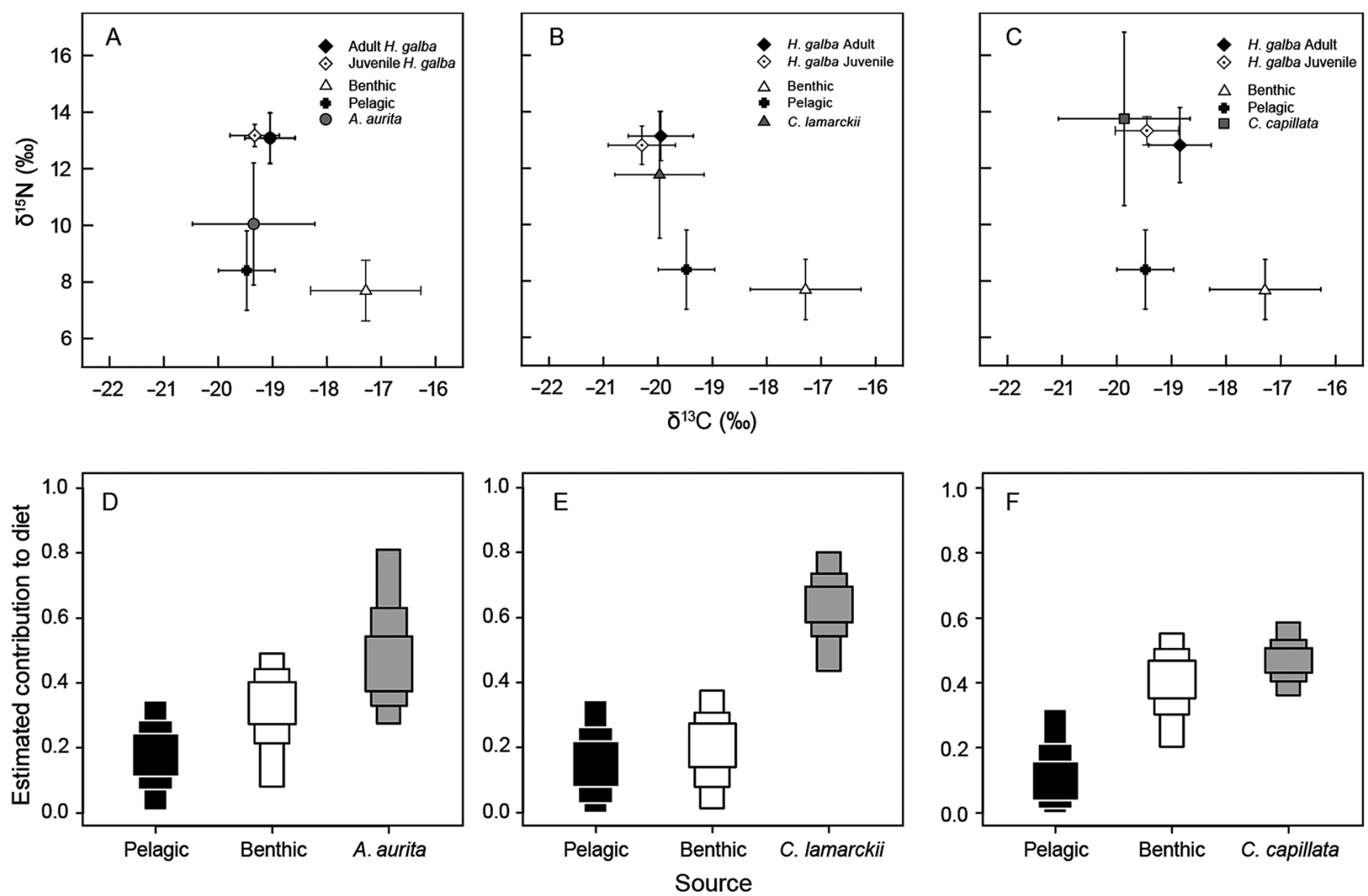

Fig. 2. Variation in mean $( \pm \mathrm{SD}) \delta^{13} \mathrm{C}$ and $\delta^{15} \mathrm{~N}$ values of Hyperia galba associated with different host species: (A) Aurelia aurita, (B) Cyanea lamarckii and (C) C. capillata. Estimated values for phytoplankton and benthic microalgae are also included as reference points for pelagic and benthic-derived $\mathrm{C}$ and $\mathrm{N}$. The stable isotope biplots highlight the decrease in the enrichment of ${ }^{15} \mathrm{~N}$ throughout the season analogous with the succession of species in the system and the time-lag of infestation (see Tables 1 \& 2). SIAR mixing model outputs with Bayesian credibility intervals $(25,75$ and $95 \%)$ are shown below, providing estimated contribution of 3 different dietary sources in H. galba associated with (D) A. aurita, (E) C. lamarckii and (F) C. capillata

was excluded from the routine as it showed colinearity with bell surface area $\left(r^{2}=0.97\right)$. None of the predictors showed a significant relationship with hyperiid density, providing no evidence of host preference (Table 5).

\section{DISCUSSION}

The potential for physical structures to aggregate, sustain and transport marine species is well documented, ranging from fish aggregating devices (FADs) for pelagic tunas (e.g. Gooding \& Magnuson 1967, Soria et al. 2009, Malone et al. 2011) through to algal rafts as dispersal vectors for a host of inter-tidal fauna (e.g. Thiel \& Gutow 2004, Clarkin et al. 2012). Although jellyfish have been documented in association with a range of vertebrate and invertebrate species, they are rarely portrayed in a positive light (Riascos et al. 2012, Doyle et al. 2014). Here, we demonstrate how scyphozoan jellyfish can provide seasonally abundant reproductive habitat and a supplementary food source for invertebrate species in coastal shelf seas.

The association between hyperiids and the 3 scyphozoan species occurred over a relatively short time frame (i.e. weeks, rather than months), despite medusae being present in the water column for 2 to 3 mo before the first appearance of Hyperia galba (Tables $1 \& 2$ ). The assertion of a short-lived association is dependent on the disappearance (i.e. mortality) of medusae at the end of the summer, following sexual reproduction (Houghton et al. 2007). Such mortality events are common in Northern Ireland, where stranding of medusae accelerates greatly during August, with large numbers of individuals washing ashore dead (Fleming et al. 2013). The cessation of these stranding events occurs simultaneously with the disappearance of medusae from Strangford Lough. We acknowledge fully that beach strandings and 
Table 4. Mean $( \pm \mathrm{SD})$ values for predictor variables used for distancebased linear model (DisLM) analysis for Aurelia aurita, Cyanea lamarckii and C. capillata. DM: dry mass

\begin{tabular}{|lccc|}
\hline Species & $\begin{array}{c}\text { Energy density } \\
\left(\mathrm{Kj} \mathrm{g}^{-1} \mathrm{DM}\right)\end{array}$ & $\begin{array}{c}\text { Surface area } \\
\left(\mathrm{cm}^{2}\right)\end{array}$ & $\begin{array}{c}\text { Wet mass } \\
(\mathrm{g})\end{array}$ \\
\hline A. aurita & $3.1( \pm 0.8)$ & $327.5( \pm 140.6)$ & $419.8( \pm 240.3)$ \\
C. lamarckii & $6.1( \pm 2.3)$ & $61.9( \pm 26.2)$ & $53.5( \pm 39.1)$ \\
C. capillata & $6.6( \pm 1.0)$ & $501.2( \pm 364.1)$ & $1135.0( \pm 1033.9)$ \\
\hline
\end{tabular}

In parallel with previous studies, initial colonisation of the host by adult amphipods was followed by the appearance of a new juvenile cohort (Fig. 1), reaffirming the importance of scyphozoans for the insertion and on-growing of broods (Dittrich 1987, 1988, 1992). This assertion is supported further by the predominant female to male ratio of amphipods in both years, the collection of females with brood in the marsupium and the visual observations of surface medusae are only indirect proxies of longevity, reflecting the reproductive seasonality of some individuals displaying semelparity, whilst others may overwinter at the seabed (Houghton et al. 2007). Indeed, Russell (1970) states that medusae that are common during the summer months at temperate latitudes tend to disappear in September and October when many dying specimens are washed ashore. However, some individuals can overwinter in deep water, with Aurelia aurita and Rhizostoma octopus taken sometimes in great numbers in fishermen's trawls (Russell 1970). Furthermore, large Cyanea capillata and R. octopus may be washed ashore from November through to January, with the latter recorded as late as March (Russell 1970, Houghton et al. 2007). Despite these flexible life history strategies, our assertion that the association between $H$. galba and their gelatinous hosts is temporary remains valid for a number of reasons. Firstly, all the medusae sampled during the spring and early summer (whether they were newly emerged that spring or had overwintered from the previous year) were not associated with hyperiids. This finding suggests either that overwintering of hyperiid-infested medusae was not common in Strangford Lough or that individuals had become dissociated from their host during the winter. Secondly, the fact that medusae were not infested with hyperiids from April through to July, in itself, indicates that the association is not permanent in such habitats. Lastly, the potential for medusae to overwinter at the seabed in a shallow water environment where current flows reach $3.5 \mathrm{~m} \mathrm{~s}^{-1}$ (Magorrian et al. 1995) seems unlikely. clustered dispersion (i.e. VMR) of H. galba (Tables 1 \& 2). Although scyphozoan jellyfish in Strangford Lough are important during the early life history of $H$. galba, it seems improbable that they are the platform on which individuals grow to reproductive maturity. For example, Dittrich $(1992,1988)$ showed that hyperiids reared at constant temperature under laboratory conditions $\left(5,10\right.$ and $\left.15^{\circ} \mathrm{C}\right)$ require between $\sim 6$ and $15 \mathrm{wk}$ to reach maturity. Given that summer water temperatures within Strangford Lough fall within this range (Fariñas-Franco et al. 2013), it is logical to assume that the developmental time frame of $H$. Galba would be similar. As colonisation of medusae by hyperiids did not occur until June or July, it is likely that there was insufficient time for individuals to reach maturity before the majority of medusae disappeared from the water column in August and September. This line of argument infers that growth in $H$. galba must continue elsewhere when scyphozoan jellyfish are no longer available, allowing the new generation to sexually mature, mate and re-colonise their gelatinous hosts the next year, although we concede that on-growing of juveniles might continue on occasion in overwintering medusae.

Questions remain, however, regarding the behaviour of hyperiids when scyphozoan jellyfish are not available. It has been suggested that $H$. galba may overwinter by entering a period of hibernation (or diapause) at the seabed (Dittrich 1988), thus conserving energy reserves accrued through predation on jellyfish. Certainly, this is the case for Arctic hyperiids (e.g. Themisto abyssorum and T. libellula), which have been shown to accumulate large deposits of wax esters (Auel et al. 2002) to allow quiescence in

Table 5. Overall 'best' solutions to host infection in distance-based linear model (DisLM) analysis. K: number of model parameters; RSS: residual sum of squared deviations

\begin{tabular}{|lcccccc|}
\hline Model & Adjusted $\mathrm{R}^{2}$ & $\mathrm{R}^{2}$ & $\mathrm{RSS}$ & Pseudo- $F$ & $\mathrm{p}$ & $K$ \\
\hline Energy density & 0.007 & 0.008 & 201.19 & 7.22 & 0.0066 & - \\
Wet mass + energy density & 0.006 & 0.009 & 200.24 & - & 0.6455 & 1 \\
Wet mass & -0.0010 & 0.0003 & 218.56 & 0.212 & 0.62 \\
\hline
\end{tabular}


months when food is limited. We provide no data to support or refute this suggestion for $H$. galba in Strangford Lough but suggest that this species spends considerably more time outside of their host (up to 44 or $47 \mathrm{wk}$ ) than in association ( 5 to $8 \mathrm{wk}$ ). This means that the 'overwintering' period for many hyperiids constitutes the majority of the year (i.e. September to June), which suggests that survival during this time through hibernation or diapause alone is unlikely. An alternative explanation can be drawn from the SIAR mixing model output, which showed that $H$. galba associated with all 3 scyphozoan species had significant benthic and pelagic components in their diet (Fig. 2D-F), although follow up studies under controlled conditions are recommended to test this hypothesis.

From an isotopic perspective, the presence of pelagic and benthic dietary components (Fig. 2) may indicate that adult $H$. galba tissues had not yet reached equilibrium with their present diet (mostly gelatinous tissue). Both $\mathrm{C}$ and $\mathrm{N}$ isotope ratios change in response to a change in diet and individual growth (isotopic turnover), but this is not instantaneous, and the isotopic ratio from the initial diet may persist for some time after the change (Tieszen et al. 1983). The proportion of benthic resource in the diet of $H$. galba found on the 3 scyphozoan species reflected the temporal pattern of infestation (e.g. individuals taken from $A$. aurita were characterised by a weaker benthic signal in comparison to those taken from $C$. capillata - the first and last species to be colonised, respectively). More precisely, the longer individuals were potentially associated with their host, the more their diet appeared reflective of gelatinous tissue (see Fig. 2, Tables 1-3).

The lack of significant difference in isotopic values between juveniles and adult hyperiids collected from each scyphozoan species was intriguing. We predicted that feeding by $H$. galba adults outside of their gelatinous host, prior to colonisation, would result in adults being ${ }^{13} \mathrm{C}$ enriched relative to juveniles, which was not supported by our data. There are 2 possible explanations for this isotopic similarity: (1) predation by both adults and juveniles on gelatinous tissue, and/or (2) the yolk-sac upon which post-embryonic larvae feed (Dittrich 1987) reflecting maternal isotopic values. Further research is required to resolve this aspect of our results. Regarding the first explanation, there was evidence that host tissue represented the largest dietary component of adult $H$. galba (constituting between $\sim 42$ and $85 \%$ of estimated assimilated diet) (Fig. 2). As hyperiid crustaceans in biotic microhabitats (i.e. gelata) are known to provide on-going maternal brood care (e.g. Thiel 2000, Gasca \& Haddock 2004), adult female $H$. galba may stay within the host's tissues for extended periods. This strategy may enable female hyperiids to supplement their energy reserves during the reproductive period, rather than jellyfish serving as their primary food source for the majority of the year. This argument is supported by the scarcity of male hyperiids in this study, which suggests that predation upon scyphozoa is not obligate. Likewise, for emerging and developing juveniles, it is likely that medusae (either in the water column or during degradation/overwintering at the seabed) provide a supplementary source of nutrition (in addition to the parental yolk sac) and shelter during early life history (Fig. 2).

Associations between $H$. galba and the 3 scyphozoan species considered here have been reported previously by Metz (1967), Russell (1970) and Dittrich (1988) amongst others. Other known hosts at temperate latitudes include Chrysaora hyscocella, $R$. octopus (Dittrich 1988) and Pelagia noctiluca (Farran 1914, as P. perla, N. E. C. Fleming pers. obs.). Despite this array of gelatinous species being used as hosts, little attention has been paid to host preference, given that many of these species co-occur (Houghton et al. 2006, 2007, Doyle et al. 2007b). Although nutritional quality best described the densities of $H$. galba on the 3 gelatinous species considered here (Table 5), its explanatory power was very low and does not present a strong case for scyphozoa being colonised preferentially in relation to their nutritional quality or morphological characteristics (Table 4). Indeed, given that all 3 scyphozoan species attained $100 \%$ prevalence during summer months, it is likely that the temporal patterns of increasing infestation reflected seasonal availability of particular species, rather than preference for a particular host (Fig. 1, Tables $1 \& 2$ ).

In summary, $H$. galba in Strangford Lough appear to use scyphozoan jellyfish primarily for reproduction and early life history development (i.e. shelter), although consumption of gelatinous tissue was high. If food acquisition was the main driver for infestation, it remains unexplained why colonisation did not occur until 3 mo after the first appearance of medusae in the water column. The limited extent of the infestation period ( $\sim 5$ to $8 \mathrm{wk}$ ) suggested that survival of hyperiids outside of medusae cannot be accounted for by hibernation alone. SIA provided evidence of assimilation of benthic and pelagic-derived $\mathrm{C}$ and $\mathrm{N}$ in adult $H$. galba prior to host colonisation, although dietary signatures were skewed towards gelatinous tissues, highlighting the need for studies when scyphozoan jellyfish are not present. 
Acknowledgements. This study was supported by a Department of Education and Learning (DEL) PhD studentship awarded to N.E.C.F. by the Northern Ireland Assembly. We are grateful to Phillip Johnston, Henk Van Rein and Julia Sigwart from Queen's University, Belfast Marine Laboratory (QML) for boat support and sample collection. Thanks also go to Eoin Bleakney, Natalie McCullagh and Niamh McNamara for help with fieldwork and sample processing and to the 3 anonymous reviewers whose comments helped improve the manuscript.

\section{LITERATURE CITED}

Anderson MJ (2001) A new method for non-parametric multivariate analysis of variance. Austral Ecol 26:32-46

Anderson MJ, Gorley RN, Clarke KR (2008) PERMANOVA+ for PRIMER: guide to software and statistical methods. PRIMER-E, Plymouth

Angel MV, Pugh PR (2000) Quantification of diel vertical migration by micro-nektonic taxa in the north-east Atlantic. Hydrobiologia 440:161-179

Auel H, Harjes M, da Rocha R, Stübing D, Hagen W (2002) Lipid biomarkers indicate different ecological niches and trophic relationships of the Arctic hyperiid amphipods Themisto abyssorum and T. libellula. Polar Biol 25:374-383

- Barbour AD, Pugliese A (2000) On the variance-to-mean ratio in models of parasite distributions. Adv Appl Probab 32:701-719

Barz K, Hirche HJ (2005) Seasonal development of scyphozoan medusae and the predatory impact of Aurelia aurita on the zooplankton community in the Bornholme Basin (central Baltic Sea). Mar Biol 147:465-476

Bond AL, Diamond AW (2011) Recent Bayesian stableisotope mixing models are highly sensitive to variation in discrimination factors. Ecol Appl 21:1017-1023

Bowman TE (1973) Pelagic amphipods of the genus Hyperia and closely related genera (Hyperiidea: Hyperiidae). Smithson Contrib Zool 136:1-76

Bowman TE, Gruner HE (1973) The families and genera of Hyperiidea (Crustacea: Amphipoda). Smithson Contrib Zool 146:1-64

Buecher E, Sparks C, Brierley A, Boyer HE, Gibbons MJ (2001) Biometry and size distribution of Chrysaora hysoscella (Cnidaria, Scyphozoa) and Aequorea aequorea (Cnidaria, Hydrozoa) off Namibia with some notes on their parasite Hyperia medusarum. J Plankton Res 23: 1073-1080

Bush AO, Lafferty KD, Lotz JM, Shostak AW (1997) Parasitology meets ecology on its own terms: Margolis et al. revisited. J Parasitol 83: 575-583

Carabel S, Godínez-Domínguez E, Verísimo P, Fernández L, Freire J (2006) An assessment of sample processing methods for stable isotope analyses of marine food webs. J Exp Mar Biol Ecol 336:254-261

Clarke KR, Gorley RN (2006) PRIMER v6: user manual/ tutorial. PRIMER-E, Plymouth

> Clarkin E, Maggs CA, Arnott G, Briggs S, Houghton JDR (2012) The colonization of macroalgal rafts by the genus Idotea (sub-phylum Crustacea; order Isopoda): an active or passive process? J Mar Biol Assoc UK 92:1273-1282

Crawley KR, Hyndes GA, Vanderklift MA (2007) Variation among diets in discrimination of $\delta^{13} \mathrm{C}$ and $\delta^{15} \mathrm{~N}$ in the amphipod Allorchestes compressa. J Exp Mar Biol Ecol 349:370-377
Dittrich B (1987) Postembryonic development of the parasitic amphipod Hyperia galba. Helgol Wiss Meeresunters 41:217-232

> Dittrich B (1988) Studies on the life cycle and reproduction of the parasitic amphipod Hyperia galba in the North Sea. Helgol Wiss Meeresunters 42:79-98

> Dittrich B (1991) Biochemical composition of the parasitic amphipod Hyperia galba in relation to age and starvation. J Comp Physiol B 161:441-449

Dittrich B (1992) Functional morphology of the mouthparts and feeding strategies of the parasitic amphipod Hyperia galba (Montague, 1813). Sarsia 77:11-18

> Doyle TK, Houghton JDR, McDevitt R, Davenport J, Hays GC (2007a) The energy density of jellyfish: estimates from bomb-calorimetry and proximate-composition. J Exp Mar Biol Ecol 343:239-252

> Doyle TK, Houghton JDR, Buckley SM, Hays GC, Davenport $\mathrm{J}(2007 \mathrm{~b})$ The broad-scale distribution of five jellyfish species across a temperate coastal environment. Hydrobiologia 579:29-39

Doyle TK, Hays GC, Harrod C, Houghton JDR (2014) The need for positive thoughts in jellyfish ecology. In: Pitt KA, Lucas C (eds) Jellyfish blooms. Springer Science+ Business Media, Dordrecht, p 105-127

Efron B, Tibshirani RJ (1993) An introduction to the bootstrap. Chapman \& Hall, New York, NY

Erwin DG (1986) Strangford Lough benthos and the marine community concept. PhD dissertation, Queen's University Belfast

Fariñas-Franco JM, Allcock L, Smyth D, Roberts D (2013) Community convergence and recruitment of keystone species as performance indicators of artificial reefs. J Sea Res 78:59-74

Farlin JP, Lewis LS, Anderson TW, Lai CT (2010) Functional diversity in amphipods revealed by stable isotopes in an eelgrass ecosystem. Mar Ecol Prog Ser 420:277-281

Farran GP (1914) Clare Island survey: notes on marine plankton. Proc R Ir Acad B 31:1-8

Fleming NEC, Houghton JDR, Magill CL, Harrod C (2011) Preservation methods alter stable isotope values in gelatinous zooplankton: implications for interpreting trophic ecology. Mar Biol 158:2141-2146

> Fleming NEC, Harrod C, Houghton JDR (2013) Identifying potentially harmful jellyfish blooms using shoreline surveys. Aquacult Environ Interact 4:263-272

> Gasca R, Haddock SDH (2004) Associations between gelatinous zooplankton and hyperiid amphipods (Crustacea: Pericarida) in the Gulf of California. Hydrobiologia 530-531:529-535

Gooding RM, Magnuson JJ (1967) Ecological significance of a drifting object to pelagic fishes. Pac Sci 21:486-497

Harbison GR, Biggs DC, Madin LP (1977) The associations of Amphipoda Hyperiidea with gelatinous zooplankton II. Associations with Cnidaria, Ctenophora, and Radiolaria. Deep-Sea Res 24:465-488

> Harrod C, Syväranta J, Kubicek L, Cappanera V, Houghton JDR (2013) Reply to Logan \& Dodge: 'Stable isotopes challenge the perception of ocean sunfish Mola mola as obligate jellyfish predators'. J Fish Biol 82:10-16

Hayward PJ, Isaac MJ, Makings P Moyse J, Naylor E, Smaldon G (1995) Crustaceans (Phylum Crustacea). In: Hayward PJ \& Ryland JS (eds) Handbook of the marine fauna of North-West Europe. Oxford University Press, Oxford, p 289-461

> Heaslip SG, Iverson SJ, Bowen WD, James MC (2012) Jelly- 
fish support high energy intake of leatherback sea turtles (Dermochelys coriacea): video evidence from animalborne cameras. PLoS ONE 7:e33259

Houghton JDR, Doyle TK, Davenport J, Hays GC (2006) Developing a simple, rapid method for identifying and monitoring jellyfish aggregations from the air. Mar Ecol Prog Ser 314:159-170

> Houghton JDR, Doyle TK, Davenport J, Lilley MKS, Wilson RP, Hays GC (2007) Stranding events provide indirect insights into the seasonality and persistence of jellyfish medusae (Cnidaria: Scyphozoa). Hydrobiologia 589:1-13

> Jacob U, Mintenbeck K, Brey T, Knust R, Beyer K (2005) Stable isotope food web studies: a case for standardized sample treatment. Mar Ecol Prog Ser 287:251-253

Kingsford MJ (1993) Biotia and abiotic structure in the pelagic environment: importance to small fishes. Bull Mar Sci 53:393-415

Laval P (1980) Hyperiid amphipods as crustacean parasitoids associated with gelatinous zooplankton. Oceanogr Mar Biol Annu Rev 18:11-56

Lindsey D, Pagès F (2010) Voragonema tatsunoko (Trachymedusae: Rhopalonematidae), a new species of benthopelagic medusa, host to the hyperiid amphipod Mimonectes spandli (Physosomata: Mimonectidae). Zootaxa 2671:31-39

> Lucas CH (2001) Reproduction and life history strategies of the common jellyfish, Aurelia aurita, in relation to its ambient environment. Hydrobiologia 451:229-246

Lynam CP, Brierly AS (2007) Enhanced survival of 0-group gadoid fish under jellyfish umbrellas. Mar Biol 150: 1397-1401

Macko SA, Lee WY, Parker PL (1982) Nitrogen and carbon isotope fractionation by two species of marine amphipods: laboratory and field studies. J Exp Mar Biol Ecol 63:145-149

Madin LP, Harbison GR (1977) The associations of Amphipoda Hyperiidea with gelatinous zooplankton - I. Associations with Salpidae. Deep-Sea Res 24:449-463

Magorrian BH, Service M, Clarke W (1995) An acoustic bottom classification of Strangford Lough, Northern Ireland. J Mar Biol Assoc UK 75:987-992

Malone MA, Buck KM, Moreno G, Sancho G (2011) Diet of three large pelagic fishes associated with drifting fish aggregating devices (DFADs) in the western equatorial Indian Ocean. Anim Biodivers Conserv 34:287-294

- Mancinelli G (2012) On the trophic ecology of Gammaridea (Crustacea: Amphipoda) in coastal waters: a European scale analysis of stable isotopes data. Estuar Coast Shelf Sci 114:130-139

Mansueti R (1963) Symbiotic behaviour between small fishes and jellyfishes, with new data on that between the stromateid, Peprilus alepidotus, and the scyphomedusae, Chrysaora quinquecirrha. Copeia 1963:40-80

Marliave JB, Mills CE (1993) Piggyback riding by pandalid shrimp larvae on hydromedusae. Can J Zool 71:257-263

Martin JW, Davis GE (2001) An updated classification of the recent Crustacea. Natural History Museum of Los Angeles County Science Series no. 39, Los Angeles, CA

McArdle BH, Anderson MJ (2001) Fitting multivariate models to community data: a comment on distance-based redundancy analysis. Ecology 82:290-297

McCutchan JH, Lewis WM, Kendall C, McGrath CC (2003) Variation in trophic shift for stable isotope ratios of car- bon, nitrogen, and sulfur. Oikos 102:378-390

Metz P (1967) On the relations between Hyperia galba Montagu (Amphipoda, Hyperiidae) and its host Aurelia aurita in the Isefjord area (Sjaelland, Denmark). Vidensk Medd Dan Nathist Foren 130:85-108

Ohtsuka S, Koike K, Lindsay DJ, Nishikawa J and others (2009) Symbionts of marine medusae and ctenophores. Plank Benth Res 4:1-13

Pagès F, Corbera J, Lindsay DJ (2007) Piggybacking pycnogonids and parasitic narcomedusae on Pandea rubra (Anthomedusae, Pandeidae). Plank Benth Res 2:83-90

> Parnell AC, Inger R, Bearhop S, Jackson AL (2010) Source partitioning using stable isotopes: coping with too much variation. PLoS ONE 5:e9672

> Post DM (2002) Using stable isotopes to estimate trophic position: models, methods, and assumptions. Ecology 83: 703-718

R Development Core Team (2012). R: a language and environment for statistical computing. R Foundation for Statistical Computing, Vienna, www.R-project.org/

Riascos JM, Vergara M, Fajardo J, Villegas V, Pacheco AS (2012) The role of hyperiid parasites as a trophic link between jellyfish and fishes. J Fish Biol 81:1686-1695

Rózsa L, Reiczigel J, Majoros G (2000) Quantifying parasites in samples of hosts. J Parasitol 86:228-232

Russell FS (1970) The medusae of the British Isles II. Cambridge University Press, Cambridge

> Sal Moyano MP, Schiariti A, Giberto DA, Diaz Briz L, Gavio MA, Mianzan HW (2012) The symbiotic relationship between Lychnorhiza lucerna (Scyphozoa, Rhizostomeae) and Libinia spinosa (Decapoda, Epialtidae) in the Río de la Plata (Argentina-Uruguay). Mar Biol 159: 1933-1941

Soria M, Dagorn L, Potin G, Freón P (2009) First field-based experiment supporting the meeting point hypothesis for schooling in pelagic fish. Anim Behav 78:1441-1446

Stephenson RL, Tan FC, Mann KH (1986) Use of stable carbon isotope ratios to compare plant material and potential consumers in a seagrass bed and a kelp bed in Nova Scotia, Canada. Mar Ecol Prog Ser 30:1-7

Thiel M (2000) Extended parental care behavior in crustaceans - a comparative overview. In: von Vaupel Klein JC, Schram F (eds) The biodiversity crisis and Crustacea. Proc $4^{\text {th }}$ Int Crustac Congr, 20-24 Jul 1998, Amsterdam. Brill, Leiden, p 211-225

Thiel M, Gutow L (2004) The ecology of rafting in the marine environment. I. The floating substrata. Oceanogr Mar Biol Annu Rev 42:181-264

Tieszen LL, Boutton TW, Tesdahl KG, Slade NA (1983) Fractionation and turnover of stable carbon isotopes in animal tissues: implications for $\delta^{13} \mathrm{C}$ analysis of diet. Oecologia 57:32-37

> Towanda T, Theusen EV (2006) Ectosymbiotic behavior of Cancer gracilis and its trophic relationships with its host Phacellophora camtschatica and the parasitoid Hyperia medusarum. Mar Ecol Prog Ser 315:221-236

Vinogradov ME, Volkov AF, Semenova TN (1996) Hyperiid amphipods (Amphipoda, Hyperiidea) of the world oceans. Smithsonian Institution Libraries, Washington, DC

> Yokoyama H, Tamaki A, Harada K, Shimoda K, Koyama K, Ishihi Y (2005) Variability of diet-tissue isotopic fractionation in estuarine macrobenthos. Mar Ecol Prog Ser 296: $115-128$ 